\title{
The Absorption Capacity of Turkey for Its Use of the European Union Pre-Accession Assistance*
}

\author{
Mustafa Duran** \\ Turkish Treasury
}

\begin{abstract}
The European Union's (EU) financial assistance is an important instrument to use in preparing Candidate Countries (CCs) for membership. The EU's financial assistance programs are implemented under the Decentralized Implementation System (DIS) in CCs. Building up an adequate institutional capacity during the accession period is of high importance for the effective use of the available resources and also for preparing the countries for their full absorption capacity of the EU's Structural and Cohesion Funds. The experiences and best practices obtained during the implementation of previous accession programs provide valuable lessons for the CCs. Experience shows that the financial allocations may not be used fully by the beneficiary countries because of many different reasons such as a complex implementation system, excessive controls, too much eligibility criteria and inadequate administrative capacity. Considerable attention is therefore devoted to analyzing and improving the performance of the financial assistance programs. Tackling the low absorption problem encountered in the Member States (MSs) and CCs is becoming one of the central issues discussed at the EU and the national levels. Turkey is benefiting from the EU's Instrument for Pre-Accession Assistance (IPA). In this study, Turkey's performance in the use of the IPA funds and the elements affecting the absorption capacity are assessed based on the experiences obtained both during the setting up of the DIS structure and in the outcomes of the implementation so far.
\end{abstract}

Keywords: absorption capacity, financial cooperation, EU pre-accession assistance, absorption rate, EU funds, $I P A$.

\section{Türkiye’nin Avrupa Birliği Katılım Öncesi Mali Yardımlarını Kullanım Kapasitesi}

\section{Özet}

Avrupa Birliği (AB) mali yardımları, aday ülkeleri birliğe hazırlama açısından önemli bir araçtır. Mali yardım programları, aday ülkelerde, merkezi olmayan bir sistem (decentralized implementation system) çerçevesinde uygulanmaktadır. Katılım sürecinde,

\footnotetext{
* The opinions expressed in this article are those of the author and do not represent the views of the Undersecretariat of the Treasury.

** Dr. Mustafa Duran is the Deputy Director General in Foreign Economic Relations in the Turkish Treasury, T.C. Başbakanlık Hazine Müsteşarlığı, Dış Ekonomik İlişkiler Genel Müdürlüğü, İnönü Bulvarı No: 36, 06510, Emek, Ankara, Turkey. E-mail: mustafa.duran@hazine.gov.tr
} 
yeterli düzeyde kurumsal kapasite oluşturulması, sağlanan fonların etkin kullanımı ve üyelik sonrası yararlanılacak Uyum ve Yapısal Fonlara hazırlık açısından hayati öneme sahiptir. Geçmişte uygulanan benzer programlardan elde edilen tecrübeler aday ülkelere önemli dersler sunmaktadır. Tecrübeler, tahsis edilen fonların yararlanıcı ülkeler tarafından karmaşık uygulama prosedürleri, aşırı kontroller, çok sayıda uygunluk kriterinin aranması ve kurumsal kapasite eksikliği gibi birçok nedene bağlı olarak tam kullanılamadığını göstermektedir. Bu yüzden, mali yardım programlarının performansını analiz etmeye ve iyileştirmeye dönük ciddi çabalar harcanmaktadır. Üye ve aday ülkelerdeki düşük fon kullanım kapasitesi sorununun çözümüne yönelik tartışmalar, $\mathrm{AB}$ kurumları ve ulusal düzeydeki merkezi konulardan biri haline gelmiştir. Türkiye, halen AB'nin katılım öncesi mali yardım programlarından (IPA) yararlanmaktadır. Bu çalışmada, Türkiye'nin fon kullanım kapasitesi ve fon kullanım kapasitesini etkileyen temel faktörler geçtiğimiz süreçte yaşanan tecrübeler ve uygulama sonuçlarından elde edilen verilerle incelenmektedir.

Anahtar kelimeler: fon kullanım kapasitesi, mali işbirliği, AB katılım öncesi mali yardımları, fon kullanım orant.

$\mathrm{T}$ The history of the financial cooperation between Turkey and the EU dates back to the 1960s. The Turkish-EU financial cooperation has been implemented under the financial protocols emanating from the 1963 Ankara Agreement that continued until the completion of the Customs Union in 1996. Three financial protocols and a complementary protocol were signed between 1964 and 1981 in order to promote Turkey's socio-economic development. However, the fourth protocol, earmarking MECU 600 , was not implemented because of Greece's veto. The assistance under the financial protocols consisted mostly of grants, particularly from the European Investment Bank (EIB) loans and from community funded loans. However, during the 32-year period, Turkey received MECU 830 out of the total allocated funds of MECU 1.433 (IKV, 2013 and Karataş, 2010).

Under the Customs Union, Turkey was able to access the EU budget resources and the EU's credit and grants. The EU financial assistance to Turkey was provided within the framework of Euro-Mediterranean Development Association (MEDA) ${ }^{[1]}$ program established in 1996. During the 1996 - 1999 periods, grants amounting to MECU 768 were allocated, but the grants provided by the EC budget amounting to MECU 375 was not used due to Greece's veto. In this period, loans mainly committed by the European Investment Bank (EIB) amounting to MECU 1.567 have been provided to Turkey, of which MECU 750 was not used, again because of Greece's veto.

In 1999, the EU recognized Turkey's status as a CC and declared that the same conditions for the other CCs would be applied to Turkey during the pre-accession period.

[1] The MEDA program is the main financial instrument for the implementation of the Euro-Mediterranean Partnership which was established at the Barcelona Conference in November 1995. Algeria, Egypt, Jordan, Lebanon, Morocco, Syria, Tunisia, Turkey, the Palestinian Authority, Cyprus, Israel and Malta have benefited from it. 
Therefore Turkey has been receiving pre-accession oriented assistance from the EU since 2001. For the program years 2002-2006 the EU's assistance was provided within the specific pre-accession oriented framework of the EU's Pre-Accession Financial Assistance for Turkey. During these four years, the EC allocated MEUR 1.282 to Turkey, of which $83 \%$ (MEUR 1.058) has been used.

Since 2007, along with all the CCs and the potential candidate countries (PCCs) for EU accession (CCs: Turkey, Croatia ${ }^{[2]}$ and the Republic of Macedonia. PCCs: Albania, Bosnia-Herzegovina, Kosovo, Montenegro and Serbia), Turkey has been a beneficiary of the EU's Instrument for Pre-Accession Assistance (IPA) in accordance with the European Union Council Regulation (EC) No 1085/2006 of 17 July 2006.

\section{IPA Funds Allocated to Turkey}

In the programming period of 2007-2013, the amount of funds available for the IPA was MEUR 11.200 of which MEUR 4.800 were allocated to Turkey. With only the EUR 10 annual per capita funds allocated, Turkey is the last among the CCs and PCCs. Table 1 shows that Montenegro received EUR 56 per capita (5 times more than Turkey), and Bosnia and Herzegovina, the second less fund receiver after Turkey, received EUR 25 (nearly 3 times more than Turkey). The average per capita funds level in the CCs and PCCs (excluding Turkey) was around EUR 37. In every respect, the size of the preaccession fund allocated to Turkey was very small compared to the other existing CCs and PCCs as well as to the previous CCs (12 new members) during their pre-accession period (the average was EUR 30). If that same average had been applied to Turkey, the annual IPA allocation in the current programming period would have been around MEUR 2.500 instead of MEUR 686.

The scarce size of the funds allocated to Turkey may give an indication that the time scale for Turkey's accession probably will be much more prolonged than for the sevenyear accession of the EU10 (Cyprus, the Czech Republic, Estonia, Hungary, Latvia, Lithuania, Malta, Poland, Slovakia, and Slovenia) 1997-2004.

The European Commission (EC) is also well aware of the fact that the level of funds allocated to Turkey is not enough to meet Turkey's investment needs as it works through its accession period. To this end, the EU tries to increase the leverage effects of the resources by blending its grants with international financial institutions (IFI) loans. In the new forms of financing of investment, the EU offers a mixture of resources involving more loans and less grants to the beneficiaries and moving away from the traditional grant-based financing. In this respect, the EC offers a blending program (Turkey Investment Program) similar to the Western Balkan Investment Facility (WBIF).

Though there is no clear formula for the EU financial allocation by countries, a certain set of criteria is cited to be taken into account for the IPA allocation (EC, 2011); it includes absorption capacity, needs assessment, respect of conditionality and capacity

[2] Croatia became EU's 28th member on 1 July 2013. However, Croatia will continue to benefit from the on-going IPA programs for the period 2007-2013 until the end of 2017. 
of management while providing flexibilities to adapt to the specific pre-accession needs of the individual countries. Indeed, Cohesion Funds are allocated to the MSs based on the GDP per capita calculated on the basis of purchasing power parity. In the past, a similar formula based on population and GDP was applied in some pre-accession financial assistance programs like the Instrument for Structural Policies for Pre-Accession (ISPA). However, the IPA allocation (in particular to Turkey) was not made by taking the population and the GDP into account.

In this respect, the EU lays more emphasis on the intangible effects of financial assistance. The EU financial instruments affect mostly the GDP, employment and its added-value which arises from other side aspects such as contributions made to regional development by strategic planning, integrated development policies, partnership evaluation, exchange of experience, know-how and good practices between regions (Tektaş and Kuyucu, 2010).

Table 1

IPA Financial Allocations by Beneficiary and by Year (EUR Million)

\begin{tabular}{l|c|c|c|c|c|c|c|c|c}
\hline Country & $\mathbf{2 0 0 7}$ & $\mathbf{2 0 0 8}$ & $\mathbf{2 0 0 9}$ & $\mathbf{2 0 1 0}$ & $\mathbf{2 0 1 1}$ & $\mathbf{2 0 1 2}$ & $\mathbf{2 0 1 3}$ & Total & $\begin{array}{c}\text { Annual } \\
\text { Average } \\
\text { Per Capita* }\end{array}$ \\
\hline Croatia & 141 & 146 & 151 & 154 & 157 & 156 & 163 & $\mathbf{1 . 0 6 8}$ & 35 \\
\hline Macedonia & 59 & 70 & 82 & 92 & 98 & 105 & 117 & $\mathbf{6 2 2}$ & 44 \\
\hline Iceland & - & - & - & - & 10 & 12 & 6 & $\mathbf{2 8}$ & 31 \\
\hline Montenegro & 31 & 33 & 35 & 34 & 34 & 35 & 35 & $\mathbf{2 3 7}$ & 56 \\
\hline Albania & 61 & 74 & 81 & 94 & 94 & 95 & 98 & $\mathbf{5 9 7}$ & 27 \\
\hline $\begin{array}{l}\text { Bosnia and } \\
\text { Herzegovina }\end{array}$ & 62 & 75 & 89 & 105 & 107 & 108 & 112 & $\mathbf{6 5 8}$ & 25 \\
\hline Serbia & 190 & 191 & 195 & 198 & 202 & 206 & 215 & $\mathbf{1 . 3 9 7}$ & 28 \\
\hline Kosovo & 68 & 185 & 106 & 67 & 69 & 69 & 74 & $\mathbf{6 3 8}$ & 50 \\
\hline Turkey & 497 & 539 & 566 & 654 & 780 & 900 & 936 & $\mathbf{4 . 8 7 2}$ & 10 \\
\hline $\begin{array}{l}\text { Regional/ } \\
\text { MBP }\end{array}$ & 109 & 136 & 166 & 144 & 179 & 174 & 190 & $\mathbf{1 . 0 9 8}$ & - \\
\hline Total & $\mathbf{1 . 2 1 8}$ & $\mathbf{1 . 4 4 9}$ & $\mathbf{1 . 4 7 1}$ & $\mathbf{1 . 5 4 2}$ & $\mathbf{1 . 7 3 0}$ & $\mathbf{1 . 8 6 0}$ & $\mathbf{1 . 9 4 6}$ & $\mathbf{1 1 . 2 1 6}$ & $\mathbf{3 4}$ \\
\hline
\end{tabular}

*Calculation made on the basis of population as of 2007 (for Serbia and Kosovo as of 2009). Source: Multi-annual Indicative Financial Framework (MIFF) for 2011-2013

Experience shows that even a small amount of EU funds cannot be fully spent if an adequate institutional capacity is not established to manage the funds. The effective management of the funds is part of the wider challenge of making effective and efficient use of the funds available. Only then can a maximum contribution be made to economic and social cohesion with the resources available. If the funds absorption capacity of the 
beneficiary is restricted, the contribution of the EU funds to the economic and social cohesion will be small and the achievement of the objectives is not likely.

\section{Conceptual Framework of Absorption Capacity}

The absorption capacity for the EU financial assistance is the key in measuring the achievement of the assistance in the beneficiary countries. Though it is of critical importance, the theoretical framework for the absorption capacity related to the EU financial assistance is lacking. The reasons given are the changing nature of the EU funds and the relative newness of the field. Hence, the absorption capacity of the EU funds is still considered to be "a work in progress" and the topic is becoming ever more interesting for the academic world (Horvat, 2004).

In particular, the new member states are suffering from a low absorption problem for utilizing their Structural Funds (up to $2-4 \%$ of their GDP); this is of crucial importance in their economic and social development. Therefore, the topic is among the top issues being discussed in the political, academic and business arenas.

Different literature sources deal with the absorption capacity. They could be classified into two main groups (Horvat, 2004): (1) macro-economic analysis and (2) different evaluation studies and reports prepared by the European Commission (EC) or by EC consultants. Sets of country-specific and multi-country studies have been conducted in order to identify the reasons behind the low absorption rates (Ernst\&Young, 2005). The main purpose of all these studies is to identify the needs for institutional building and to improve the countries' capacity to absorb the EU funds.

The existing literature on the absorption capacity of the EU funds does not offer a unique definition for the term. Most definitions are based on the capacity of a country to absorb the allocated EU funds, with the most emphasis on the quantitative aspects. However, some others point out the qualitative aspects that the absorption capacity indicates. They point to the degree that a country is able to effectively and efficiently spend the EU financial assistance in order to make the maximum contribution to the essential objectives of economic and social cohesion. According to this view, the absorption capacity only leads to a strong performance with the EU funds if the economy, the efficiency and the effectiveness are fully taken into account (Sumpikova et.al, 2004).

The EC defines the absorption capacity as the extent to which a state (member or candidate country) is able to spend the allocated financial resources fully and in an effective and efficient way (EP, 2011). The absorption capacity is usually measured by absorption rates. In the EU evaluation practice, even the effectiveness of funds is also measured through the absorption rates. This understanding is criticized in the recent European Court of Auditors Reports which says that the main focus should be given on value for money rather than absorption rate.

The absorption rate therefore illustrates the absorption capacity and is defined as the spent of the total amount of funds available (Horvat, 2004). Achieving an absorption rate of $100 \%$ means that all the funds allocated to a country have been fully utilized. Therefore if a country is unable to achieve a $100 \%$ utilization of its allocation, it is 
considered to have an absorption problem (Viladimira and Vinko, 2013).

The absorption capacity is determined by three main factors, namely (1) the macroeconomic situation, (2) the co-financing situation and (3) the administrative capacity (NEI, 2002).

The Macro-Economic Absorption Capacity is defined and measured in terms of the GDP. The upper limit has generally been defined by the EC as $4 \%$ of the GDP of the respective member state. For the candidate countries, this rate is limited to the allocated amount defined in the Multi-annual Indicative Financial Framework (MIFF) and is far less than that of the threshold for the member states.

The Co-financing Absorption Capacity is defined as the ability to co-finance the EU-supported programs and projects, to plan and guarantee the national contributions in the multi-annual budgets, and to collect these contributions from the several partners interested in the program or project.

The Administrative Absorption Capacity is defined as the ability and skill of the central and local authorities to prepare suitable plans, programs and projects in due time, to decide on programs and projects, to arrange co-ordination among the principle partners, to cope with the administrative and reporting requirements, and to finance and properly supervise the implementation, avoiding irregularities as much as possible.

The administrative capacity of a country has, in fact, two components;

On the demand side, the capacity is determined by the ability to generate adequate projects to absorb the allocated funds. Experience has shown that the beneficiary countries face difficulties in developing a sufficient project pipeline to ensure the full use of the available funds.

On the supply side, the capacity is determined by ability of a country to manage the funds efficiently and effectively. The skills and experience of the available human resources affect their ability to detail tasks and responsibilities at the level of job descriptions, to specify the required qualifications of staff, and to fulfill the requirements. Securing the timely availability of experienced, skilled and motivated staff is a key factor to success in managing the funds. Measuring the supply side of the administrative capacity starts with an analysis of three design variables: Structure relates to the clear assignment of responsibilities and tasks to institutions, or more precisely, to the departments or units within these institutions. Human resources relates to the ability to estimate the required number and the level of qualification of the staff, to allocate tasks and responsibilities to job descriptions for particular posts, and to meet these needs through the recruitment of the appropriate staff. Tools relate to the availability of various kinds of job-aids including instruments, methods, guidelines, manuals, systems, procedures, etc. that can enhance the system's functioning effectiveness.

The actual number of human resources needed to implement and manage projects co-financed by the EU funds mostly depends on the type of projects. While the staffing requirement is relatively modest in the big infrastructure projects (roughly MEUR 15 per staff, per year), in the case of the business-supported moderate projects (about MEUR 3 to 5 per staff, per year) in the small and medium enterprises' (SME) support schemes, the vocational training or agricultural grants may need the highest level of 
human resources per project. This means that not only the funding level but also the number of projects appears to be a determinant of the staffing requirements. In common cases, the focus is on the quantitative requirements in terms of the number of required staff for the effective operation of institutions. However, the experience has demonstrated that the effective and efficient management of the EU funds depends heavily on having highly qualified, motivated and experienced staff (NEI, 2002).

Table 2 shows the key absorption indicators for the CCs which were developed by the NEI (2002). The level of the absorption capacity of a country depends to a large extent on the effective designing and functioning of all these stages.

Table 2

\section{Key Absorption Indicators for Candidate Countries}

\begin{tabular}{|c|c|c|c|c|}
\hline \multirow{2}{*}{ INDICATOR } & \multicolumn{3}{|c|}{ DESIGN } & \multirow{2}{*}{ FUNCTIONING } \\
\hline & Structure & Human Resources & System \& Tools & \\
\hline Management & $\begin{array}{l}\text { Designation } \\
\text { of Managing } \\
\text { Authority }\end{array}$ & $\begin{array}{l}\text { Staffing of } \\
\text { Managing } \\
\text { Authorities }\end{array}$ & $\begin{array}{l}\text { Arrangement for } \\
\text { delegating tasks }\end{array}$ & $\begin{array}{l}\text { Existence of a } \\
\text { modern civil } \\
\text { service }\end{array}$ \\
\hline Programing & $\begin{array}{l}\text { Partnership already } \\
\text { present }\end{array}$ & $\begin{array}{l}\text { Capacity to carry } \\
\text { out programing }\end{array}$ & $\begin{array}{l}\text { Guidelines / } \\
\text { manuals for } \\
\text { programing } \\
\text { existence }\end{array}$ & $\begin{array}{l}\text { Existence } \\
\text { and quality } \\
\text { of a National } \\
\text { Development Plan }\end{array}$ \\
\hline Implementation & $\begin{array}{l}\text { Assignment of } \\
\text { Intermediate } \\
\text { Bodies }\end{array}$ & $\begin{array}{l}\text { Staffing of } \\
\text { Intermediate } \\
\text { Bodies }\end{array}$ & $\begin{array}{l}\text { Existing } \\
\text { operational } \\
\text { projects } \\
\text { development and } \\
\text { management } \\
\text { process }\end{array}$ & $\begin{array}{l}\text { Absorption of and } \\
\text { project pipeline } \\
\text { for pre-accession } \\
\text { funds }\end{array}$ \\
\hline $\begin{array}{l}\text { Evaluation \& } \\
\text { Monitoring }\end{array}$ & $\begin{array}{l}\text { Designation } \\
\text { of monitoring } \\
\text { and evaluation } \\
\text { responsibilities }\end{array}$ & $\begin{array}{l}\text { Availability of } \\
\text { independent } \\
\text { evaluation } \\
\text { expertise }\end{array}$ & $\begin{array}{l}\text { Existence of a } \\
\text { computerized } \\
\text { monitoring and } \\
\text { evaluation system }\end{array}$ & $\begin{array}{l}\text { Functioning } \\
\text { monitoring system } \\
\text { for pre-accession } \\
\text { funds }\end{array}$ \\
\hline $\begin{array}{l}\text { Financial } \\
\text { Management } \\
\text { \&Control }\end{array}$ & $\begin{array}{l}\text { Designation of } \\
\text { Paying Authorities } \\
\text { and functions }\end{array}$ & $\begin{array}{l}\text { Accounting and } \\
\text { auditing expertise } \\
\text { secured }\end{array}$ & $\begin{array}{l}\text { Existence of } \\
\text { accounting system } \\
\text { and financial } \\
\text { procedures secured }\end{array}$ & $\begin{array}{l}\text { Established } \\
\text { practice for dealing } \\
\text { with financial } \\
\text { irregularities }\end{array}$ \\
\hline
\end{tabular}

Source: NEI, 2002

The low absorption of the EU funds is mainly attributable to the weak management capacity of the relevant institutions which are in charge of the programming, selection, evaluation and monitoring of projects, and to the insufficient number of experienced staff who are poorly motivated, underpaid, and overworked. The study on the determinants of the absorption capacity and the influence of the use of pre-accession assistance in Croatia revealed a high level of correlation between the utilization of financial resources and the absorption capacity in that when the absorption capacity increased by one percent, the use of the pre-accession assistance increased by $4.8 \%$ (Viladimira and Vinko, 2013). 


\section{The Absorption Capacity of Turkey for the EU Funds}

In this section, Turkey's absorption capacity of EU financial assistance will be assessed within the conceptual framework set out above.

\section{Macro-economic Absorption Capacity}

As known, Turkey is among the countries listed as best in terms of their speed of economic growth during the last decade. Taking the amount of the funds allocated to Turkey under the IPA into consideration (EUR 4.8 billion over the financial period of 2007-13, which is equal to some MEUR 685 per year and is $0.12 \%$ of GDP), it is clear that the Turkish economy has a potential to absorb much more. The allocation rate is by far less than the $4 \%$ of GDP ceiling being applied to the MSs.

The above figure clearly indicates that the macro-economic absorption capacity was not a constraint for Turkey's effective and efficient use of allocated EU funds in the form of pre-accession assistance channeled through the IPA.

\section{Co-Financing Absorption Capacity}

At the same time, in the area of public finance, there has been a significant improvement and the budget deficit has been reduced to a reasonable level (range of $1-1.5 \%$ ). In view of that, and regarding the co-financing absorption capacity of Turkey for the EU funds, there has been no problem experienced so far. If an average national public co-financing rate of $25 \%$ is applied, the total amount required for national public cofinancing can be roughly estimated around MEUR 125 per year, which is equal to $0.9 \%$ of its annual budget.

Due mainly to the robust stance of the public finance of Turkey, even during the recent crises, there has not been a noteworthy financial restraint such as austerity measures on its public institutions, unlike many MSs who did have to control the massive amount of their public deficit in order to meet the economic criteria of the EU. With their dynamic positions and high economic growth rates, the Turkish private companies that applied for the EU funded projects are also in a good position to meet their private contribution requirements (an overall rate of 50\% in the IPA Rural Development - IPARD).

It is clear also that co-financing was not an obstacle to Turkey's absorbing the EU funds to date, nor is it envisaged to be a problem in the remaining period. These facts indicate that the national co-financing of the EU funded programs and projects represent a relatively small proportion in this segment of the central government budget and of the GDP of Turkey. Consequently, the financial absorption capacity and ability to provide national co-financing are not a concern for the absorption of EU funds in Turkey.

On the other hand, the sound public finance position of Turkey did have an adverse impact on the utilization of the EU funds due mainly to the easy access to the national public sources during the current financial period.

\section{Administrative Absorption Capacity of Turkey}

As mentioned earlier, the administrative capacity of countries is assessed in two different categories: demand side and supply side. 


\section{The Demand Side of the Administrative Absorption Capacity (Project Pipeline).} Turkey, a fast developing middle-income country, needs to invest large amounts in order to close the income gap with the EU as well as with other developed countries. In order to fulfill the obligations stemming from EU membership, a substantial financial and technical assistance investment will be required in the areas of education, human resource development, employment, environment, energy, transport, competitiveness and innovation, infrastructure, agriculture and rural development.

Within the context of Turkey's "vision 2023" (relative to the $100^{\text {th }}$ anniversary of the Republic), Turkey has set forth its goals to be met by 2023. Among these goals, the investment project packages only in the transport, environment and energy sectors amount roughly to EUR 300 billion. The projects already in the pipeline are expected to be financed through public resources, public-private partnerships (PPP) and the private sector.

The real figures realized so far may give a fair vision of the potential demand level for the EU funded programs: For example, in the IPARD program, 12 different calls have been conducted so far with a response of 11.714 project applications valued at MEUR 1.969. The total value of the projects under the last two calls amounts to MEUR 1.450 while the available funds allocated to the IPARD is only MEUR 850 for the whole period. Only $28 \%$ of the applicants have been contracted and funded, while the rest have not. The same potential also exists in the Transport and Environment Operational Programs (OPs). It can be concluded that on the demand side, there is no significant obstacle to fully absorbing the available EU funds.

The Supply Side of the Administrative/Institutional Absorption Capacity. During the programming period (2007-2013), re-designing the existing institutions in line with the EC's requirements has been a time-consuming process. It was a challenging process to set up a new structure, a new reporting line and a new hierarchy within an established system without adverse effects on the system.

At the beginning of the period, Turkey experienced difficulties in terms of building up an adequate institutional capacity at all levels of the DIS institutions in a timely manner. In some cases, new parallel institutions had to be established, such as the Central Finance and Contracts Unit (CFCU) and the IPARD Agency. The completion of the required legal framework and the recruitment of an adequate number of qualified staff have also taken a long time. Moreover, new Province Coordination Units (PCUs) have been established in 42 provinces under the IPARD program, and almost 1900 new staff have been recruited along with providing the adequate office space, tools, and training. As of the end of 2013, the total number of staff working in the DIS bodies reached 2450, excluding public staff working in the Senior Program Officers (SPOs) and the intermediate bodies. Taking the additional workload due to the IPA II for the upcoming period into consideration, there is a need for about 200 more staff to meet the needs in the whole system. This does not present a significant risk.

A comparison of the per staff funds level in the CCs can give valuable insight in identifying the human resources needed relative to funding the level to be administered. During their pre-accession period, one staff member managed MEUR 4.0 in Slovenia, 
MEUR 1.2 in Estonia, MEUR 3.7 in Slovakia, MEUR 3.5 in the Czech Republic, and MEUR 1.4 in Hungary (Horvat, 2004). This shows the big differences among countries in the amount of per staff funds that were managed. In Turkey, the per staff funds in the current programming period is MEUR 1.9, a better position relative to the other countries.

However, it is interesting to note that the IPARD program has been overstaffed with only MEUR 0.4 (1900 staff members have managed MEUR 855 over the period). The staffing capacity already built up in the IPARD program could not be justified at the current funding level, including the IPA II period (2014-20), proposed by the EC to be roughly MEUR 800.

The dilemma here is that the accession process is envisaged to take a reasonable time frame for the CCs, but the accession period for Turkey seems to be taking a long time and membership still remains an open question. In this respect, the challenge is whether the capacity to be established should target the existing pre-accession funds level or the membership funds level (Cohesion and Structural Funds).

Another difficulty experienced is concerned with the long-term retention of qualified staff at the IPA related institutions. Due mainly to the differences of salary among institutions, the qualified staff working in the line ministries, especially those who have a command of English, are inclined to move on to other institutions where better salaries are provided. This has led to a high staff turnover in some Operating Structures (OS) and has caused serious difficulties in maintaining a stable structure; it also has contributed to a delay in the implementation process. Within the context of the re-structuring process in the public sector, the salary issue in the OSs was addressed in 2011. Accordingly, the staff turnover in the OSs has remained stable to a large extent since then.

\section{The Current Status of the IPA Implementation in Turkey}

In this section, information on the three key ratios, the contracting rate, the payment rate and the de-commitment rate in each program under the IPA, is presented and the fundamental reasons affecting the absorption rate are assessed for each program according to their particular nature. The actual performance of the absorption rate of the EU funds in Turkey is illustrated in the Table 3.

\section{TAIB Programs (Component I)}

The Transition Assistance and Institution Building Component (TAIB) covers the institution-building measures and the associated investments supporting the transition to a democratic society and a market economy, and helping strengthen the democratic institutions, the administrative and judicial capacity, and the civil society.

The total EU allocation for Component I is MEUR 1.667 for the financial period of 2007-13. The conferral of management decision for this Component was taken by the EC in the last quarter of 2008 and the first financing agreement was signed that same year. As of the end of 2013, there are two programs of which the contracting deadlines have passed, namely the 2007 and 2008 national programs. The contracting rates for these programs were $89 \%$ and $94 \%$, respectively. For the other programs (the 
2009, 2010, 2011, 2012 and the 2013 national programs) the contracting and payment deadlines have not expired yet. The overall contracting rate for all national programs under Component I is $56 \%$ (MEUR 928) and the payment rate is $48 \%$ (MEUR 794).

The other key indicator to evaluate the implementation performance is the decommitment rate. For the programs for which the contracting deadline has passed, the de-commitment rate is 3\% (MEUR 51.3) of the total allocation for this Component. The main reasons for the de-commitment experienced under this Component so far are tender savings and tender failures. Of these main reasons, the distribution of the decommitment from the tender savings was $86 \%$ and from the tender failures was $14 \%$. A main concern about the program has been that the public institutions which are the major beneficiaries/receivers of the project applications have been reluctant to apply because completing the applications was time consuming and the project approval and implementation process was of long duration. However, compared to the other Components, in terms of contracting and payment rate, this Component seems in a better position.

The CFCU, the contracting authority for this Component, has gained experience and knowledge since 2002. It employs more than 100 staff, which is sufficient to perform its responsibility. The main problem here has been that the staff turnover rate in the CFCU is relatively high due to its unusual institutional structure in public administration. But it has been provided with the opportunity to manage its weaknesses in this respect. Another positive development regarding this Component is that the $\mathrm{EC}$ is considering taking the conferral of management decision for the EDIS within 2014. This will help accelerate the implementation process. However, there is a need for further strengthening of the programming and monitoring capacity in this Component. The National IPA Coordinator (NIPAC) Secretariat, in charge of programming and monitoring, has around 30 staff and there is a need for 10 additional staff to enhance its staffing capacity in line with the updated workload analysis. Consequently, no significant de-commitment risk is expected under Component I in the remaining period. The structure established has enough capability to overcome the challenges ahead and possible temporary setbacks.

\section{Regional Development Component (Component III)}

The Regional Development Component supports investments in transport, environment and economic cohesion, and in associated technical assistance. Participating in such programs should help beneficiary countries use the EU regional funding more effectively once it becomes available after accession.

Environment OP. The amount of funds allocated by the EC for the Environment Operational Program (EOP) over the current programming period is MEUR 682. The conferral of management decision for Component III was made by the EC in the second half of 2009. As of the end of 2013, the contracting rate is 41\% (MEUR 277) and the payment rate is $18 \%$ (MEUR 123). The de-commitment rate thus far is $8 \%$ (MEUR 55) of the total allocation. Even though this OP has a sufficient project pipeline to enable the full absorption of the available funds, due mainly to inadequate institutional capacity caused by the restructuring process in the line ministries in 2011, the contracting 
and payment levels were relatively low and therefore some funds were lost. The main concern for this program is the delay in the contracting and implementation processes. The time is narrowing for the implementation mainly of the major projects under the program. Therefore, the projects in the pipeline should be contracted within 2014 or at the latest early 2015. Otherwise, a further de-commitment is likely to take place and the completion of some projects will not be possible within their payment deadlines.

Table 3

IPA Performance of Turkey as of the end of 2013 (EUR Million)

\begin{tabular}{l|l|l|l|l|l|l|l}
\hline Components & Committed & Paid & $\begin{array}{l}\text { Paid } \\
\text { Rate } \\
(\mathbf{\%})\end{array}$ & Contracted & $\begin{array}{l}\text { Contracted } \\
\text { Rate } \\
(\%)\end{array}$ & $\begin{array}{l}\text { Lost } \\
\text { Lost } \\
\text { Rate } \\
(\%)\end{array}$ \\
\hline Component I & $\mathbf{1 , 6 6 7 . 5}$ & $\mathbf{7 9 3 . 5}$ & $\mathbf{4 8}$ & $\mathbf{9 2 8 . 2}$ & $\mathbf{5 6}$ & $\mathbf{5 1 . 3}$ & $\mathbf{3}$ \\
\hline Component II & $\mathbf{2 0 . 6}$ & $\mathbf{2 . 3}$ & $\mathbf{1 1}$ & $\mathbf{6 . 1}$ & $\mathbf{3 0}$ & $\mathbf{5 . 1}$ & $\mathbf{2 5}$ \\
\hline Component II & $\mathbf{1 , 7 4 7 . 6}$ & $\mathbf{3 6 3 . 6}$ & $\mathbf{2 1}$ & $\mathbf{7 1 1 . 3}$ & $\mathbf{4 1}$ & $\mathbf{1 0 9 . 5}$ & $\mathbf{6}$ \\
\hline Environment OP & 682.5 & 122.8 & 18 & 277.4 & 41 & 54.6 & 8 \\
\hline Transport OP & 584.7 & 157.3 & 27 & 324.6 & 56 & 7.5 & 1 \\
\hline Regional Com. OP & 480.4 & 83.5 & 17 & 109.3 & 23 & 47.5 & 10 \\
\hline Component IV & $\mathbf{4 7 3 . 9}$ & $\mathbf{1 3 4 . 1}$ & $\mathbf{2 4}$ & $\mathbf{1 3 2 . 5}$ & $\mathbf{2 8}$ & $\mathbf{1 2 . 4}$ & $\mathbf{3}$ \\
\hline Component V & $\mathbf{8 5 4 . 6}$ & $\mathbf{1 4 7 . 0}$ & $\mathbf{1 7}$ & $\mathbf{2 1 3 . 2}$ & $\mathbf{2 5}$ & $\mathbf{6 4 . 9}$ & $\mathbf{8}$ \\
\hline TOTAL & $\mathbf{4 , 7 6 4 . 2}$ & $\mathbf{1 , 4 4 0 . 7}$ & $\mathbf{3 0}$ & $\mathbf{1 , 9 9 1 . 4}$ & $\mathbf{4 2}$ & $\mathbf{2 4 3 . 2}$ & $\mathbf{5}$ \\
\hline
\end{tabular}

Sources: National Fund, Turkish Treasury

In addition to that, the absorption level in the remaining period depends on the completion of the building up of a sound institutional capacity in the Operating Structure (OS) in order to manage the program effectively. The Operating Structure has 45 staff, but needs 60 to 70 to effectively perform their responsibilities.

Transport OP. The allocation for Transport OP is MEUR 585 for the programming period (2007-13). The contracting and payment rates are higher than the other OPs under Component III mainly because of the fact that the program is composed of a few big projects. The contracting rate recorded thus far is 56\% (MEUR 325) which is the highest level along with Component I and the payment rate is $27 \%$ (MEUR 157). As for the de-commitment rate, it is the lowest with $1 \%$ only (MEUR 7.5). With the remaining part of the funds, only one big project could be financed. A significant de-commitment risk for the remaining period is not expected if a new big work project is contracted within 2014. Both sides are well aware of the fact that the time to implement such a big process is narrowing. A possible delay in the approval process or the tendering and contracting processes may cause a huge amount of funds lost (MEUR 250). 
In this operational program, due to the existence of only a few large projects, the staffing need is limited. Twenty-five personnel are employed under the OS. The main concern about the capacity is that the OS does not have the adequate experience in tendering and contracting processes for big projects since the previous two big transport projects were launched and contracted by the CFCU.

Regional Competitiveness OP. The other OP under Component III is Regional Competitiveness. The aim of this program is to support the improvement of the business environment, to strengthen the enterprise capacity, and to foster entrepreneurship. The EU allocation for this operational program in the programming period of 2007-13 is MEUR 469. As of the end of 2013, the contracting rate has been 23\% (MEUR 109) and the payment rate $18 \%$ (MEUR 84 ). The de-commitment rate thus far has been $10 \%$ (MEUR 47.5), corresponding to the highest level in all the IPA programs excluding Component II, which is managed by Bulgarian and Romanian authorities. Looking at the details of poor performance, several fundamental factors among many others appear to have had a significant impact, namely the insufficient number of mature projects to enable to the absorption of available funds, the inadequate institutional capacity, and the frequent $^{[3]}$ change of senior managers within the IPA Unit. The main part of the funds loss with a value of MEUR 36 has taken place in 2013.

The OS employs around 70 staff, but the program covers a large number of grants and small projects, which require more staff. Therefore, in order to manage the implementation process effectively, a further strengthening of the institutional capacity is needed. Due to a delay in implementation, some additional funds are likely to be lost in the remaining period.

\section{Human Resources Development OP}

The Human Resources Development OP is aimed at supporting the development of human capital and at helping reduce social exclusion. The IPA assistance in this area contributes to improving work skills, creating more and better jobs and increasing social inclusion and equality. The amount of the EU allocation for the entire period is MEUR 480. The conferral of management decision was taken by the EC in the last quarter of 2009. As of the end of 2013, the contracting rate is 35\% (MEUR 165) and the payment rate is $28 \%$ (MEUR 134). This OP is seen to be in a better position in terms of its payment rate with the advantage of direct grant schemes; however, it is considered weak in terms of its contracting rate. As regards the de-commitment rate, the OP is in the second best position with a $3 \%$ rate just after the Transport OP. The close cooperation and collaboration between the OS and the DG EMPLY of the EC have played a crucial role in the achievement of this performance.

The management of this program, like the Regional Competitiveness OP, is relatively challenging compared to the others as it is mainly composed of small-scale grants and small projects. For this reason, the OS employs around 120 staff. The OS has enough capacity to manage the program effectively. It does not seem any significant decommitment risk in the future in terms of the administrative capacity in this program.

[3] Since 2007, the head of the Operating Structure has changed 4 times and the head of IPA Unit has changed 6 times. 


\section{Rural Development OP}

The IPARD program is important in preparing Turkey for the Common Agricultural Policy of the EU. The EU allocation for this OP in the entire period of 2007-13 has been MEUR 855. The conferral of management decision was taken by the EC in two stages: in the first stage the decision for central bodies and 20 PCUs was made in the second half of 2011, and in the second stage the decision for 22 PCUs was made in the second half of 2013. Due to the delay in the conferral of management decision, the implementation has started too late. Hence, the contracting rate thus far is $25 \%$ (MEUR 213), while the payment rate is $17 \%$ (MEUR 147). Both rates are the lowest among all the OPs.

Regarding the de-commitment rate, the OP has lost $8 \%$ (MEUR 65) of the available funds for the current programming period. In particular, the allocation for 2009 which should have been used by the end of 2012, could not be disbursed due to the time constraint caused by the requirements of the " $n+3$ ' rule" (the funds allocated for each year must be spent by the end of the third year). Even though there was much justification for pre-financing (an instrument helping minimize de-commitment risk), the DG AGRI did not provide pre-financing in 2012 owing to the insufficient disbursement expectation in 2013. Then, 65 million euros was lost in one single year (in 2012). However, the payment execution with the value of MEUR 134 has exceeded the minimum disbursement amount of MEUR 132.

The IPARD Agency has 42 PCUs and employs around about 1900 staff. Furthermore, the Managing Authority, in charge of monitoring the program, employs around 40 staff. It seems that the capacity established in this program is more than enough. Regarding the project pool to be financed by the EU funds, the program is in a good position, since the sector targeted is big and the demand is high. Therefore, in the upcoming period, a further de-commitment is not expected.

In sum, as of the end of 2013, the figures show that the overall absorption rate for all the IPA Components is $30 \%$ (EUR 1.4 billion), the contracting rate is $42 \%$ (EUR 2.0 billion) and the de-commitment rate is 5\% (MEUR 243) of the total EC allocation for the entire period. According to the EC calculation (including pre-financing), the overall payment rate is $40 \%$ (MEUR $1.440+$ MEUR 465). The use of the funds has gradually increased starting from MEUR 136 in 2009, MEUR 159 in 2010, MEUR 283 in 2011, and MEUR 367 in 2012 and going to MEUR 496 in 2013. However, the payment amount should be further increased to the level of MEUR $700-800$ on a yearly average in the remaining period in order to absorb the funds available.

It is worth pointing out here that if the cash advances (pre-financing) amounting to MEUR 465 had not been transferred and deemed as disbursement by the EC, the amount of de-commitment would have been much more than the actual level (the contribution of the cash advance to decreasing de-commitment in all OPs has been around MEUR 420).

\section{Absorption Rate in the Other CCs}

In order to evaluate the absorption performance that Turkey has achieved so far, it should be compared with the figures of the other CCs, namely Croatia and Macedonia 
(because in the other CCs and PCCs, implementation is limited to component I). Actually, in analyzing the results to get a fair judgment from this comparison, the amount of allocated funds, the economic size, the implementation modality and the conferral processes must be born in mind.

Table 4

Status of Implementation of Financial Assistances per Country as of the end of 2012 (EUR Million)

\begin{tabular}{l|c|c|c}
\hline Countries & Committed & Paid & Paid Rate (\%) \\
\hline Croatia & $\mathbf{7 8 7}$ & $\mathbf{2 9 2}$ & $\mathbf{3 7 . 1}$ \\
\hline Com. I & 242 & 138 & 57.0 \\
\hline Com. III & 329 & 89 & 27.1 \\
\hline Com.IV & 86 & 35 & 40.7 \\
\hline Com.V & 130 & 30 & 23.1 \\
\hline Macedonia & $\mathbf{4 9 8}$ & $\mathbf{1 4 8}$ & $\mathbf{2 9 . 7}$ \\
\hline Com. I & 202 & 79 & 39.1 \\
\hline Com. III & 200 & 48 & 24.0 \\
\hline Com.IV & 33 & 10 & 30.3 \\
\hline Com.V & 63 & 11 & 17.5 \\
\hline Turkey & $\mathbf{4 . 2 6 1}$ & $\mathbf{1 . 4 8 1}$ & $\mathbf{3 4 . 8}$ \\
\hline Com. I & 1,390 & 772 & 55.5 \\
\hline Com. III & 1.747 & 519 & 29.7 \\
\hline Com.IV & 474 & 109 & 23.0 \\
\hline Com.V & 650 & 81 & 12.5 \\
\hline Total & $\mathbf{5 . 5 4 6}$ & $\mathbf{1 . 9 2 1}$ & $\mathbf{3 4 . 6}$ \\
\hline
\end{tabular}

Sources: EC, 2012 Annual Report on Financial Assistance for Enlargement.

The latest available data (as of the end of 2012) on the implementation results of the IPA countries reported by the EC (2013a) show that for Component I, the payment rate is $57 \%$ in Croatia, $39 \%$ in Macedonia and $56 \%$ in Turkey. For Component III, the payment rate is $27 \%$ in Croatia, $24 \%$ in Macedonia and 30\% in Turkey. For Component IV, the payment rate is $41 \%$ in Croatia, $30 \%$ in Macedonia and $23 \%$ in Turkey. For IPARD, the payment rate is $23 \%$ in Croatia, $18 \%$ in Macedonia and $13 \%$ in Turkey. It should be noted that the EC counts all fund transfers made to beneficiary countries as payment including the pre-financing which has not been disbursed in the beneficiary country yet. That is why the payment rate in the EC figures is higher than the figures in Table 3. As of the end of 2012, while the absorption rate was $20 \%$ in Turkey, this rate is shown in EC figures as 35\% (the difference is MEUR 534, which is made up of the sum of the amount that was transferred by the EC to the National Funds account as pre-financing - MEUR 461 and by the amount for projects directly managed by the EC-MEUR 73). 
The total payment rates (excluding Component II) is $37 \%$ (MEUR 292 out of a total MEUR 787 allocation) in Croatia, 30\% (MEUR 148 out of a total MEUR 498 allocation) in Macedonia and 35\% (MEUR 1.481 out of a total MEUR 4.261 allocation) in Turkey. Croatia records the highest absorption rate with $37 \%$, Turkey is in second place with $35 \%$ and Macedonia records the lowest rate with $30 \%$.

These figures show that there is no big difference in the absorption rates among the three countries. A reasonable explanation could be the amount of funds, the geographical coverage of programs and the accreditation and conferral processes which are crucial for kick-starting the implementation and use of the funds.

\section{Absorption Rate in Member States}

From the start of the EU integration process in 1958, there has been a strong political will to reduce the economic and social disparities between different regions of the $\mathrm{EU}$, since economic activities, income levels and the level of unemployment are not evenly spread across the European Union. For the programming period 2007-2013, the policy of economic and social cohesion has a budget of MEUR 348.415 out of MEUR 976.443, with three main objectives, namely convergence (82\% of Structural Funds -SF), Regional Competitiveness and Employment (16\% of SF) and European Territorial Cooperation ( $2 \%$ of SF). The programming budget is supported by structural instruments (the European Regional Development Funds -ERDF, the European Social Fund -ESF and the Cohesion Fund - CF). There are also two major complementary funds which are the European Agricultural Fund for Rural Development (EAFRD) and the European Fisheries Fund (EFF) with the total budget of MEUR 412.611 under heading 2 (Preservation and Management of Natural Resources). Even though the instrument for the Pre-Accession Assistance for the candidate and potential candidate countries is a financial instrument facilitating the European Cohesion Policy, it is not a part of the budget of the Cohesion Policy. The IPA allocation is placed under heading 4 (the EU as a global player) with EUR 11.2 billion, equal to one percent of the total EU budget.

The low absorption problem in the MSs is considered one of the main issues to be solved, and it is getting worse year by year. The most critical results drawn from the performance of the MSs suggest that the implementation of the 2007-2013 programs lags well behind those in earlier periods. By the end of 2011, five years into the programming period, it is estimated that payments to the EU15 amounted to only $34 \%$ of the total funding available for the whole period. The corresponding rates for the 20002006 period and the 1994-1999 period are 44\% and 55\%, respectively (EC, 2013a).

According to the latest Commission figures (EC, 2013c) on the implementation of the Cohesion Policy, the picture across the MSs is diverse. The absorption is higher in Estonia, Portugal, Lithuania, and Ireland (within the range of 70-80\%). Lower absorption rates have been recorded in Romania, Slovakia, Bulgaria, Italy and Malta (within the range of 35-50\%). There is a big difference among the MSs regarding their absorption rate, which ranges from $35 \%$ to $80 \%$. The average absorption rate is $61 \%$, meaning that EUR 206 billion out of the total EUR 338 billion allocations has been disbursed. It should 
be noted that the financial rules in the MSs differ from those of the CCs; furthermore, the CCs have had to spend a long time to build up a new system, while the MSs have been able to start using funds right after their allocation.

The EC has identified some factors which delayed the absorption of funds in the MSs in the 2007-2013 period. Those include the late start of programs due to the extension of the previous period, the lack of administrative capacity, the challenges in preparing major infrastructure projects and obtaining EC approval, the change in legislation, the inconsistent political ownership, the international economic crisis, the changes in national/regional governments, and the effects of national sector reforms (EP, 2013). In 2011, to increase the absorption capacity in the MSs, the Council and the Parliament (EP) adopted a regulation allowing a temporary increase of EU co-financing rates by $10 \%$ for the MSs experiencing financial difficulties. In 2013, the EC proposed additional measures to reduce the risks for some MSs of losing unspent funds.

\section{Absorption Rate in Previous Pre-Accession Programs}

There were five different EU pre-accession financial assistance programs (PHARE, CARDS, ISPA, SAPARD and the Turkey Pre-accession Instruments) before the IPA, for which the contracting and payment deadlines have expired. The implementation modality of the said programs and the length of period for the utilization of the funds for each beneficiary country differ depending on their entry date to the EU. For that reason, the absorption performance of each country needs to be assessed within the context of its own nature.

The latest available figures released by the EC (2013a) show that in the period of 1990-2009, the total budget allocation of the PHARE program (Poland and Hungary: Assistance for Restructuring their Economies) was EUR 19.2 billion; of which EUR 16.1 billion was paid, corresponding to a $84 \%$ absorption rate. The absorption rate varies among 16 beneficiary countries from $55 \%$ (the lowest rate was recorded in Croatia with 55\%) to $92 \%$ (the highest rate was recorded in Hungary and Slovenia with $92 \%$ ). Some other examples are; East Germany was able to use MEUR 28.8 out of the allocated MEUR 34.4 (the absorption rate was 84\%), Bulgaria used EUR 1.8 billion out of EUR 2.3 billion allocated with the rate of 76\%, Romania used EUR 2.9 billion of EUR 3.6 billion allocated with the rate of $81 \%$. As can be seen, there is no country which recorded a $100 \%$ absorption rate under this program.

Another pre-accession assistance program in effect before the IPA is the CARDS (Community Assistance for Reconstruction, Development and Stabilization), which covers 8 countries. The total amount of funds allocated for this program is EUR 4.1 billion. The overall absorption rate is recorded as $92 \%$ representing EUR 3.8 billion of payments made. The highest rate has been recorded in Montenegro with 98\%, which has a relatively small program with a value of MEUR 127 total allocations. The lowest rate has been recorded in Albania with 75\% (EC, 2013a).

The SAPARD (Special Accession Program for Agriculture and Rural Development) was established in 1999 to help ten countries of Central and Eastern Europe deal with 
the problems of the structural adjustment in their agricultural sectors and rural areas. The SAPARD program has been closed at different times depending on their entry date to the EU for the eight new MSs (CZ, EE, HU, LV, LT, PI, SK and SI) in 2004 and for two new MSs (Bulgaria and Romania) in 2007. While average absorption rate for the eight countries is around $99 \%$, for the last three beneficiary countries; Bulgaria, Romania and Croatia it is $88 \%$ (EC, 2010).

In the period of 2002-2006, the EU implemented a special program for Turkey under the name of the Turkey Pre-accession Instruments. Its contracting deadline expired in 2009. Based on the latest available date of the National Fund, the EU allocation was MEUR 1.282, of which MEUR 1.058, representing 83\% absorption rates, has been used. The absorption rate by Turkey in this program is close to the average absorption rate in the PHARE program.

\section{Common Reasons for the Absorption Problem in Turkey}

Based on experiences obtained throughout the periods of setting up of the DIS/EDIS system and during the implementation process, a set of reasons for the relatively low rate (or de-commitment) in the IPA programs in Turkey are presented below under two broad categories;

\section{Reasons Stemming from the European Commission:}

- lack of sufficient guidance at the beginning of the process,

- delay in putting the EC regulations into force,

- delay in the conferral of management decisions (up to $1-3$ years),

- delay in the pre-approval process by the EC for the major projects (1 - 2 years),

- delay in the ex-ante approval of the EC delegation (4 - 6 months),

- lack of staff capacity and a coordination problem between or within the DGs.

\section{Reasons stemming from the national structure:}

- introduction of a new management and control system,

- delays in the fulfillment of the requirements of accreditation criteria,

- delay in building up an adequate institutional capacity and the completion of the legal basis,

- lack of ownership and enthusiasm at the management level,

- tender savings and tender failures (especially in Component I),

- delay in the programming phase,

- weak project pipelines,

- unsound procurement plans,

- excessive bureaucratic procedures and controls modality (in the IPARD, three different level controls),

- excessive and costly application requirements (particularly in the IPARD),

- long preparation process for the major projects (2 - 4 years), 
- delay in the procurement process (8 - 10 months),

- low quality of tendering documents,

- high rejection rates (IPA I - IV),

- slow progress of projects contracted and therefore delays in the payment claims.

As can be seen from the above list, a number of reasons have impacted the absorption capacity for the EU funds. Of course, each reason is not relevant for all programs and does not have the same impact on each program. However, there is a consensus that the absorption problem depends mostly on the institutional factors, both at the EU and the national levels.

Some of the critical reasons for the absorption problem require a broad assessment in order to see the root cause of the problems. The fundamental reasons for the delay in the implementation process under the Components I and III-IV are linked to the fact that the contracting functions of OSs (Environment, Competitiveness, Transport and Human Resources Development OPs) have been temporarily delegated to the CFCU which is responsible for contracting projects in Components I and II, thus causing the CFCU to become overloaded and to delay the implementation of the respective programs under Component I. It has also caused delays in building up the institutional capacity in the relevant OSs. Furthermore, the relevant OSs have not been able to take over the delegated responsibilities within the planned time frame, which should have been completed by the end of 2010. So, an approximately one year delay in the process has taken place and subsequently the implementation has lagged behind the schedules set in the respective OPs. If at the beginning of the process, the institutional capacity in the OSs had been completed on time and the said functions had not been delegated to the CFCU, the implementation of projects both in Component I and Components III- IV could have started earlier and the problems of overloading and fund losses might not have occurred.

A challenging IPARD program, which requires the establishment of a wide-ranging institutional structure across 42 provinces in Turkey and demands a high number of staff for implementation, has been the main reason for the delay in the completion of the necessary structure and the conferral of management process. In addition to that, the inadequate numbers of auditors in the DG AGRI as well as more demanding accreditation criteria due to the requirement of the EDIS prolonged the conferral of management decision process, and these delayed the start of the implementation of the IPARD program.

The delay in the accreditation/the conferral of management decision process is one of the main reasons for the weak absorption rate realized so far, in particular in Components III, IV and V. Compared to Croatia, the conferral of management decisions were completed with almost a one year delay in Components III and IV (in Croatia in the last quarter of 2008, in Turkey in the second half of 2009), and with more than two years in Component V (in Croatia in the last quarter of 2009, in Turkey for the first phase in the second half of 2011, and for the second phase in the second half of 2013). Even in the SAPARD program, which was more rigid compared to the IPARD, the average 
duration of the conferral decision for the eight candidates countries took around 21 months (Konya, 2012). This took around 42 months (after the first year, 2007 of the current programming period) for the first phase and 78 months for the second phase of the IPARD program in Turkey. Furthermore, although now into the eighth year of the programming period, some measures under the IPARD program (measures; 102, 201, 202 and 501) have not yet been accredited.

Due to the nature of the EU programs, several bodies (both from the EC and the national level) are involved in the implementation processes. This requires close coordination and collaboration among the relevant bodies for smooth implementation. The experience of Turkey also confirms those of the other countries. As Horvat said, there is "a golden rule" of EU funds absorption: the smaller the number of institutions involved in implementation of financial instruments the more likely the state records a higher rate of absorption of funds (Horvat, 2004). Therefore, the main responsibility should be given to the OSs in order to make them fully undertake the ownership of the respective program. In case of the several coordinator bodies involved in the implementation process, the OSs are likely to be reluctant to assume full responsibility.

Other critical reasons are related to the lack of a target date and to a number of uncertainties on the road to Turkey's EU membership; these have strongly affected the ownership and commitment at the management levels. One study (EC, 2011) confirms that the current IPA programs work best where: a) there is a strong political and social will backed by public consensus and support for accession in the CCs and PCCs, b) the socio-economic conditions are relatively good and are improving, and c) the accession is foreseeable. If the EU accession process is foreseeable, the necessary efforts would be made by high level management, especially in building up a strong and stable institutional capacity because there would be significant increases in the funding level after membership. The fundamental objective of the pre-accession funds is to prepare the CCs for the structural and cohesion funds which will be available after membership. It is difficult to find sufficient justification to build up a strong institutional capacity where there is no clear signal or clear road map to membership.

The small size of the IPA funds allocated to Turkey is also another reason for the insufficient enthusiasm and for the delay in building up a strong institutional capacity in some OSs to manage those funds. Actually, more than 1900 staff has been recruited and 42 regional offices have been established under the IPARD program to use MEUR 855 over the current period. That size of the structure could be justified only if the EU accession is in the near future and if Turkey will be eligible for the CAP funds which will be at least ten times higher than the current funding level. Otherwise, the cost effectiveness (the administrative cost of the ARDSI which is responsible for the implementation of the IPARD program is around MEUR 95 per year, or MEUR 665 for seven years, equal to $78 \%$ of the total funds), and the rationality of the IPARD program with the existing funding level will be questioned. That level of high administrative costs cannot be sustainable in the long run. While the other IPA programs are running with a reasonable level of administrative costs, around MEUR 20 on yearly average, representing $4 \%$ in the EC allocation, the IPARD program makes the overall administrative cost of the IPA programs 
high, and increases the overall rate up to $17 \%$ (115x7:4.795). The reasons behind the high administrative cost particularly in the IPARD program are the excessive controls. ${ }^{[4]} \mathrm{It}$ should be noted that the average administrative cost of the Structural Funds in the MSs is around $2 \%$ and yet the EC seeks for actions to further decrease it (EC, 2012).

Though the cost effectiveness issue is not part of this study, there is a close link between the cost and the implementation process. Excessive controls and too much eligibility criteria for access to the funds are the essential reasons for this high cost; this also creates a cumbersome process which leads to a slow implementation and a low absorption rate where the $\mathrm{n}+3$ rule is applied along with automatic de-commitment.

\section{Role of EC on the Absorption of Funds}

All the procedures for managing and implementing the funds are often long, cumbersome, and demanding on human resources, which at the end often give rise to complaints such as, "EU funds are not worth the efforts" (Horvat, 2004).

The role of the EC on the absorption of the funds cannot be underestimated where it is authorized with the ex-ante approval as well as with the approval of the major projects. In the beginning of the programming period, the implementation regulation for the EU funds came into force after a long delay, which has caused consequent delays in the programming and the conferral of management processes. Also, in the implementation process, the ex-ante approval and the pre-approval process for the major project are running slow, and the rigid implementation rules are causing a slowdown in the implementation of the projects. In order to minimize the problems stemming from the EC administration, which have adverse effects on the use of the funds, some measures could be taken at the EC level such as, (1) accelerating the implementation of the EDIS, (2) increasing the limits for major project application/approval from MEUR 10 to MEUR 30 , and (3) achieving the simplification and flexibility in the system (implementation and control procedures). Consequently, the EC can play a critical role as a catalyzer or as a deterrent during the implementation process. Bodies involved in the implementation process of the EU assistance hold a common view that "EU funds could be spent to the extent that EC allows."

\section{Conclusion}

The EU funding system is based on a rigorous system of management, monitoring and control. Experiences gained from the implementation of the EU assistances in the past show that zero loss (or a 100\% absorption rate) in the EU financial assistance programs are hard to achieve. Therefore, it is not easy to set a benchmark for the absorption rate to assess the performance of the beneficiary country. A set of elements has an impact on the absorption capacity of a country for the EU financial assistance.

[4] One of the findings set out in the European Court of Auditors Report for the IPARD program was that some of the projects had been audited 18 times by national bodies until their mission date. In addition to that, these projects will subject to further controls by the end of its completion. 
In terms of the macro-economic and co-financing absorption capacity, Turkey holds a great potential due to the fact that the amount of available funds is very limited; in fact it is at a negligible level when compared to the EU average (2-3\% of their GDP). Taking into account several factors like investment need, project development capacity, magnitude of investment projects undertaken or planned in eligible sectors for EU financial assistances (transport, energy, environment, etc.), and co-financing capacity, Turkey has a big absorption potential for the EU funds.

Research on the issue and the experiences obtained so far demonstrates that a sound institutional structure is one of the strongest criteria to be taken into account for an effective management of the EU funds. Though significant improvements have been made in building up an institutional structure to effectively manage the IPA funds in Turkey, there is a need to further strengthen the administrative capacity in some OSs in order to effectively use the funds available and to implement them in a timely manner. Otherwise, the inadequate institutional capacity will curtail the full use of the available funds.

The actual absorption rates realized so far in Turkey can be seen as reasonable compared to the other CCs. The de-commitment rate realized in all the IPA programs is 5\% which represents a MEUR 243 of the total funds loss. In the remaining period, the same amount of funds (about MEUR 250) is likely to be lost. Consequently, for the entire period, a target rate of $90 \%$ absorption seems attainable unless unexpected significant risks occur along the way. Any ratio below this rate may require more particular attention and careful analysis.

\section{References}

Alina-Stefania, U. (2009). "Reform Perspectives for Cohesion Policy in the Budget Review Process," 22-25 April, 2009, Los Angeles, CA. Available [online] at: http://www.euce.org/eusa2009/papers/ ujupan_09A.pdf

Avrupa Birliği Genel Sekreterliği (2007). Avrupa Birliği Türkiye Mali İşbirliği (EU-Turkish Financial Coopration). Duman Ofset Matbaas1, Ankara.

Bocean G. C. (2012). Absorption Capacity of EU Funds in Romania, Management- Marketing- Tourism. Available [online] at: http://feaa.ucv.ro/RTE/018-14.pdf

Cace, C., Cace, S., and Nicolaescu, V. (2010). "Management of the Structural Funds within the context of the Global Economic Crisis," Review of International Comparative Management, 11, March. Available [online] at: http://www.rmci.ase.ro/no11vol1/Vol11_No1_Article8.pdf

EBRD and IMF (2011). "The Role of Commercial Banks in the Absorption of EU Funds," Brussels. Available [online] at: https://www.imf.org/external/region/eur/pdf/2011/ebci031611a.pdf

Ernst \& Young (2005). Accessing EU Funds in the New Member States: Best Practice from around Europe, The Economist. Available [online] at: http://bit.ly/1vIBODM

European Commission (2010). SAPARD Annual Report Year 2009. Available [online] at: http:// www.parliament.bg/pub/ECD/92364COM_2010_567_EN_ACTE_f.pdf

------, (2011). Evaluation to Support the Preparation of Pre-Accession Financial Instruments Beyond 2013. Available [online] at: http://bit.ly/1ufuNaB 
------, (2012). Measuring the Impact of Changing Regulatory Requirements to Administrative Cost and Administrative Burden of Managing EU Structural Funds. Available [online] at: http://bit.ly/1vIENMp ------, (2013a). 2012 Annual Report on Financial Assistance for Enlargement. Available [online] at: http://bit.ly/1plr3i3

, (2013b). Report from the Commission to the European Parliament, the Council, the European Economic and Social Committee and the Committee of the Regions. Available [online] at: http:// bit.ly/1nRZvBD

------, (2013c). Regional Policy web page: http://ec.europa.eu/regional_policy/thefunds/funding/ index_en.cfm

European Parliament (2011). Absorption of Structural and Cohesion Funds: Lessons Learnt for the Future Cohesion Policy of the EU, Working Document. Available [online] at: http://bit.ly/1A1Foqp

-----, (2013). The Low Absorption of EU Structural Funds. Available [online] at: http://bit.ly/lnuxHDs

Georgescui, G. (2008). "Determinants of Increasing EU Funds Absorption Capacity in Romania," Annales Universitatis Apulensis Series Economica, 2(10): 16-24. Available [online] at: http:// www.oeconomica.uab.ro/upload/lucrari/1020082/16.pdf

Horvat, A. (2004). "Regional Development, Absorption Problems in The European Union's Structural Funds; Some Aspects Regarding Administrative Absorption Capacities in the Candidate Countries;" Vienna University of Economics and Business Administration; Ph.D. thesis. Available [online] at: http://www-sre.wu.ac.at/ersa/ersaconfs/ersa04/PDF/591.pdf

IKV, Turkey-EU Financial Co-Operation. Available [online] at: http://bit.ly/1B9MJX8

Kalman, J. (2002). "Possible Structural Funds Absorption Problems - The Political Economy View with Application to the Hungarian Regional Development Institutions and Financial System." http:// lgi.osi.hu/publications/2002/105/Marcou-Hungary.pdf

Karataş, H. (2010). Avrupa Birliği Katılım Öncesi Mali Yardımları (Financial Instruments for PreAccession Assistance). Maliye Bakanlığı Yayını, No: 2010/409, Ankara.

Konya, E. (2012). Impact of the SAPARD Programme on the Rural Development System in EasternCentral European Countries, Doctoral Thesis, Szent Istvan University, Gödöllö. $\quad$ Available [online] at: https://szie.hu//file/tti/archivum/Konya_Edit_thesis.pdf

Madalina, E. O. (2012). "Evaluation of the Structural Funds Absorption Rate by Means of the Mermin Model," Annals of the University of Oradea, Economic Science Series; 21(1): 332.

Mrak, M. and Tilew, D. (2008). Absorption for EU Pre-Accession Funds: Concept and Implications for Kosovo, KCSF. Available [online] at: http://bit.ly/1vICZ68

NEI (2002). "Key Indicators for Candidate Countries to Effectively Manage the Structural Funds;" Principal Report, Final Report, prepared by the NEI Regional and Urban Development for the EC DG REGIO/DG ENLARGEMENT, Rotterdam, February. Available [online] at: http://www.evaluace.cz/ dokumenty/hodnot_zpr_eu/souhrnna_studie.pdf

Oprescu, G., Lumini, D., Illie, F., and Pislaru, D. (2005). Analysis of Absorption Capacity of the EU Funds in Romania, European Institute of Romania, Pre-Accession Impact Studies, Study No.1.

Sumpikova, M., Pavel, J., and Klazer, S. (2004). EU Funds: Absorption Capacity and Effectiveness of Their Use with Focus on Regional Level in the Czech Republic, Conference on Problems Facing the New Member States. Retrieved: 02.05.2008. Available [online] at: http://unpan1.un.org/intradoc/ groups/public/documents/nispacee/unpan018547.pdf 
Tektaş, A. and Kuyucu, H.A.D., (2010). "Comparative Performance Assessment In EU Pre-Accession Funds," New, Advanced Technology. Available [online] at: http://www.intechopen.com/download/ get/type/pdfs/id/10738

Vladimira, I., Vinko K., and Jelena, K. (2013). "Absorption Capacity of European Union Pre-accession Programs in Croatia," Institute of Economic Science, 46(1/2). Available [online] at: http://www.ien. bg.ac.rs/index.php/en/2013/2013-1-2

World Bank (2007). Administrative Capacity in the New EU Member States. Available [online] at: http://elibrary.worldbank.org/doi/pdf/10.1596/978-0-8213-7155-8

Zaman, G. and Georgescu, G. (2009). "Structural Fund Absorption: A New Challenge for Romania?" Romanian Journal of Economic Forecasting, 1/2009. Available [online] at: http://www.ipe.ro/rjef/ rjef1_09/rjef1_09_10.pdf 


\section{List of Acronyms}

ARDSI

CAP

CARDS

$\mathrm{CC}$

$\mathrm{CF}$

CFCU

$\mathrm{CU}$

DG AGRI

DG EMPLY

DG REGIO

DIS

EAFRD

EC

ECP

EDIS

EFF

EIB

EOP

EP

ESF

ERDF

EU

EUR

EUSCF

GDP

IFI

IPA

IPARD

ISPA

MBP

MECU

MEDA

MEUR

MIFF

MS

NEI

NIPAC

OP

OS

PCC

PCU

PHARE

PMNR

PPP

SAPARD

SF

SME

SPO

TAIB

WBIF
Agricultural Rural Development Support Institution

Common Agricultural Policy

Community Assistance for Reconstruction, Development and Stabilization

Candidate Country

Cohesion Funds

Central Finance and Contracts Unit

Customs Union

Agriculture and Rural Development - Directorate-General

Employment, Social Affairs and Inclusion - Directorate-General

Regional Policy - Directorate-General

Decentralized Implementation System

European Agricultural Fund for Rural Development

European Commission

European Cohesion Policy

Extended Decentralized Implementation System

European Fisheries Fund

European Investment Bank

Environment Operational Program

European Parliament

European Social Fund

European Regional Development Funds

European Union

Euro

European Union Structural and Cohesion Funds

Gross Domestic Product

International Financial Institution

Instrument for Pre-Accession Assistance

IPA Rural Development

Instrument for Structural Policies for Pre-Accession

Multi Beneficiary Program

Million ECU

Euro-Mediterranean Development Association

Million Euros

Multi-annual Indicative Financial Framework

Member State

Netherland Economic Institute

National IPA Coordinator

Operational Program

Operating Structure

Potential Candidate Country

Province Coordination Unit

Poland and Hungary: Assistance for Restructuring their Economies

Preservation and Management of Natural Resources

Public-Private Partnership

Special Assistance Program for Agricultural Rural Development

Structural Funds

Small and Medium Enterprises

Senior Program Officer

Transition Assistance and Institution Building Component

Western Balkan Investment Facility 